\title{
GENETIC DIFFERENCES IN HUMORAL IMMUNE REACTIONS OF DOMESTIC FOWL (GALLUS DOMESTICUS L.)
}

\author{
E. PETROVSKÝ ${ }^{1 *} \mathrm{~V}$. BENDA ${ }^{1+}$ and JAROMIRA KALOVA ${ }^{2}$
}

1 Institute of Animal Physiology and Genetics, Czechaslovak Academy of Sciences, 10400 Prague, Department of Farm Animal Morphology and Physiology, University of Agriculture, 613000 Brno

Received October 30, 1987

Abstract

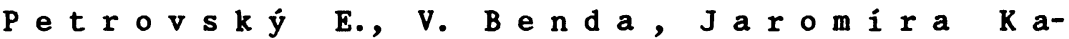
1 o $v$ á: Genetic Differences in Humoral Immune Reactions of Domestic Fow1 (Gallus domesticus L.). Acta vet. Brno, 57, 1988: 111-121.

The formation of agglutinins was observed using hens of four commercial lines of the White Leghorn (WL) and Rhode Island Red and White (RI) breeds and twelve groups of their crosses. The females aged 14 months were i.v. immunized simultaneously with two antigens, namely Brucella abortus and sheep red blood cells. The immunization was made twice, the interval being 10 days, and the titres of antibodies were determined on $10 \mathrm{th}$ and 15th days of the experiment. The results showed that the titres of antibodies to the former antigen were higher in all experimental groups and in both responses. Differences were found between the lines, both within the WL and RI breeds, on the one hand, and between these breeds, on the other: in the WL breed the responsiveness to B. abortus was higher, whereas to sheep red blood cells it was lower. Moreover, patroclinity was observed in the hybrids with either antigen. Relations between the titres of antibodies to either antigen were also different in the breeds and crosses possessing different paternal forms.

Domestic fowl, antibodies, Brucella abortus, sheep red blood cells, line and interbreed differences, patroclinity.

The commercial pressure exerted on the utilization of genetic resistance to diseases and stress situations has recently been increasing in the sphere of domestic fow1 breeding, included being both the egg-laying and meat-producing types. To define indicators of this kind of resistance is a task of material importance for the trend envisaged, because they could help us detect the morphological or functional variations applicable in

* E. Petrovský deceased in August 1988 
the differentiation of resistant bitds from susceptible individuals as early as possible and without exposing them to the action of pathogens (H u t $\mathrm{t}$ 1963).

Within the framework of the trend in research outlined above, more and more attention has been given to the immune system of an organism as the carrier of differences in resistance to diseases. The problem of genetic determination of immune responsiveness in the variety of its forms is one cardinal point of the studies. Importance of major histocompatibility complex, of immunoglobulin allotypes and/or loci that determine further traits of domestic fowl, such as the sex-linked type of plumage or dwarfism, is considered from this point of view ( $P 1 \mathrm{a} c \mathrm{~h} \dot{\mathrm{y}}$ and. B e $\mathrm{nd}$ a 1983; va $n$ d e r Z i j p p 1983; N O r d s k o g 1984; K 1 i n g e n$\mathrm{s} \mathrm{m} i \mathrm{t}$ et al. 1983; $\mathrm{B}$ a c o $\mathrm{n}$ et al. 1986; $\mathrm{G}$ y 1 e s et al. 1986). The use of divergent selection to produce lines characterized by high and low immune responses to a certain antigen, such as sheep red blood cells (henceforth only SRBC) or Salmonella pullorum, is another methodical approach to solution of this problem (U b o s i et al. 1985a,b; $D u n n i n g t \circ n$

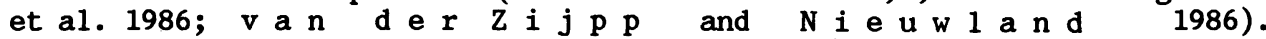
From the results of their observations the authors conclude existence of appreciable variability in immunological reactions manisfesting itself in diversity of the observations made by individual authors, both with respect to immune responses and correlated reactions, and to its immune control as we11; in complex natural immunogens the polyfactorial inheritance is referred to and, conceivably, determination by the sex-linked major gene as well.

Results of our studies with populations of egg-laying hens following simultaneous applications of $B$. abortus (henceforth only BA) and SRBC confirmed the fact described earlier, namely that the method used for immunization (intravenous - i.v., intramuscular - i.m. and intraperitoneal i.p.) significantly affected the antibody response only in the case of the latter antigen, as reported by $\mathrm{v}$ a $\mathrm{n}$ e $\mathrm{r} \mathrm{Z} j \mathrm{j}$ et al. (1986). However, it was found that this factor markedly determined the dependence of primary and secondary responses with both antigens, and with both responses as we11, in that the relationship between primary and secondary responses was significant in either antigen, and also between the levels of antibodies to the two immunogens, only following the i.m. immunization with incomplete adjuvans ( $P$ e $t r o v s k \dot{y}$ et al. 1987a). An analysis of the antibody responses in WL and RI birds and their reciprocal crosses suggested that an interaction with the sex may have played the role of an important factor for the genetic determination with respect to the genetic background; in hybrids the level of antibody response was associated with the parental position in which the initial populations were found when used for the crossing ( $P$ e $t r \circ v k \dot{y}$ et al. 1987b).

This paper deals with the variability observed in the antibody responses to two antigens, namely BA and SRBC, in hens of four lines of the egg-laying type and in hybrids of all the combinations possible within scope of the experiment.

\section{Materials and Methods}

The experimental material used in this study consisted of hens aged 14 - 15 months and belonging to two WL lines for the production of Shaver Starcross 288 hybrids, to one RIR and one RIW line for the formation of Babcock B-380 hybrids and all 12 possible types of their diallelic crossings. The birds were pedigree progenies of 16 males (four per line) and 64 females (sixteen per line). Four clinically healthy individuals were 
selected from each of the sixteen groups and injected intravenously $1 \mathrm{ml}$ of $5 \% \mathrm{SRBC}$ and $5 \% \mathrm{BA}$ (strain: S99-Weybridge exposed to heat-killing and preserved in phenol; manufacturer: BIOVETA Ivanovice na Hané, Czechoslovakia) on 1st and 10th days of the experiment. Heparinized blood plasma to determine the titre of agglutinins was sampled from the wing vein on 10 th and 15th days of the experiment.

The antibodies to SRBC were determined using microagglutination plates (U-shape bottom) and the agglutinins to $\mathrm{BA}$ using macrotitration in test tubes. For the purpose of statistical analysis the titre was expressed as $\log _{10}$ of the reciprocal value of maximum dilution at which the agglutination was still observable ( $\mathrm{G} 1 \mathrm{e} \mathrm{s}$ et al. 1986).

The statistical analysis included the calculation of following items: principal statistical characteristics and coefficients of determination, $\mathbf{r}^{2}$, of the titres of antibodies to the antigens used in the experiment. The differences found between the groups diverse in genetic respects were assessed using the analysis of variance and the t-test. Besides, the F-value was employed for testing the coefficient of determination.

\section{Results}

The observations described above furnished data relating to characteristics of the antigens used in this trial and to reactiveness of the hens from groups different in genetic respects.

It is evident from Figs. 1 - 4 that the formation of antibodies in response to $\mathrm{BA}$ antigen was markedly different from the reaction to SRBC, both in primary and secondary responses.

One difference referred to the intensity of immune reactions and its change following the second immunization. The titres of agglutinins to BA were higher in all of the experimental groups. The total mean titres of antibodies to BA were slightly higher in secondary responses $(2.57$ and 2.80 , respectively), in contrast to the respective values of 0.70 and 1.24 for SRBC indicating a marked increase. The variability in antibody responses was another remarkable difference observed between the immunogens used in this study. Concerning the antibodies to BA, the variability was lower as a rule, and it was approximately the same in both primary and secondary responses. Unlike this, the variability in agglutinins to SRBC was much higher, with a marked decrease occurring in the other analysis. This was documented by the coefficients of variance whose values varied within $6-46 \%$ and $6-25 \%$ for the antibodies to BA and within $13-141 \%$ and $16-70 \%$ for the agglutinins to SRBC. 
Moreover, an evaluation of the importance of genetic disposition for antibody responsiveness of the individuals with different genotypes pointed to marked differences, too (Figs. 1 - 4).

Within the primary responses to BA, several striking facts were found. Thus, in the WL and RI breeds (Shaver and Babcock, respectively), differences were recorded which, though not at a level of significance due to the high variability, gave the impression that the genetic contrast manifested itself also in trese traits as a result of breeding for the heterosis effect, this statement being based on the repetition of differences in the secondary response to this antigen and in the first analysis of antibodies to SRBC (in the RI breeds, also in the second analysis ).

The tendency to produce differences in reciprocal crosses, which is a special feature of hybrids, was distinct and significant in WL-1 $x$ RIR, RIR $x$ RIW hybrids and when those of WL $x$ RI were compared as a whole. For all of the crosses manifested a clear relation of the titre of antibodies to immunological reactivity of the line in paternal position, which reflected in significant differences among the RIR $x$ WL-1, RIW $x$ WL-1 and RIR, $x$ RIW crosses and their maternal lines.

A general comparison of the WL and RI lines pointed to higher immunological reactivity of the former lines to BA. It is true that the interbreed difference mentioned above was not at the level of significance, but it was manifested together with the patrocliny described above - in significantly higher titres of antibodies in WL-1 $x$ WL-2 and WL-2 $x$ WL-1 hybrids, compared with RIR $x$ RIW and RIW $x$ RIR hybrids, and further, in an analogical and significant difference between the interbreed WL $x$ RI and RI $x$ WL crosses.

Concerning the secondary response to BA, practically all of the phenomena described above were retained: the differences between WL and RI lines and breeds, the interbreed difference distinguished by a higher responsiveness of the WL breed and the patrocliny in hybrids. In several cases, however, deviations were recorded from the more or less invariable situations observed in primary responses. This applied to either interbreed hybrid of the WL-1 line and, consequently, to the interbreed crosses in general. 


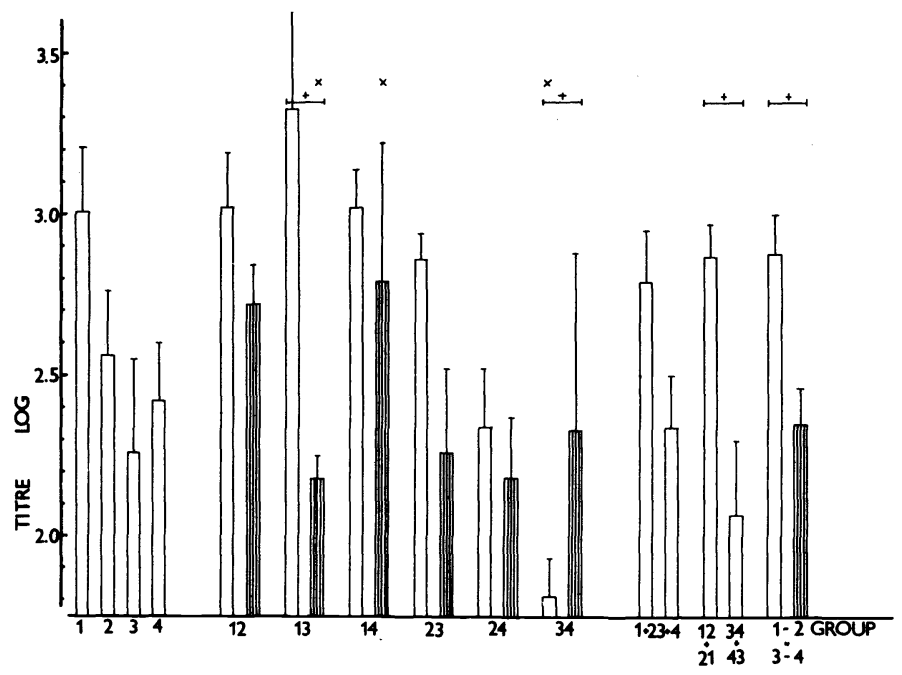

Fig. 1. Primary antibody response to BA (mean, S.E.M.). The experimental birds were of WL-1 (1), WL-2 (2), RIR-B (3), RIW-D (4) lines, their crosses (empty columns) and reciprocals (hatched columns). $x,+=$ means different at the $\mathrm{P}<0.05$ level of significance.

A major difference in the antibody reaction to SRBC lay in changed character of the interbreed difference in immunological responsiveness, when the RI breeds showed a higher reactivity in general and with repetitions. With the patrocliny manifesting itself also in this immunogen it was ascertained that at least in primary responses the antibody titres were usually higher with the opposite groups than this was the case with BA. One significant exception to the patroclinous tendency mentioned above was found in each of the two analyses; these exceptions occurredwith hybrids of the RIR line. All relevant results are shown in Figs. 3 and 4.

The genetic background affected significantly the relationships between the titres of antibodies to either antigen, both with regard to dependence of the levels of antibodies in the primary and secondary responses to the same antigen and with respect to relationship in the response to different immunogens (Tab. 1). No relationship was observed between the primary and secondary responses to SRBC. Unlike this, a covariance was recorded in the case of $\mathrm{BA}$, primarily in groups of the WL breed and progenies of the males of this breed. The genetic background markedly manifested in the correlation between the titres of antibodies to BA and SRBC; in groups of the WL breed and in hybrids - progenies of the males of this breed the values of respective coefficients of determination were low and revealed a tendency to de- 
creasing in the secondary response, while in groups of the RI breeds and in progenies of the RI males (RIR and RIW lines, RIR $x$ RIW, RIW $x$ RIR, RIR $x$ WL and RIW $x$ WL hybrids) this relationship revealed a different character: it was low in primary responses, whereas in secondary responses the coefficients of determination were high and significant.

\section{Discussion}

The considerable differences found in the results of our experimental observations, which follow from comparison of the results reported by other authors with our data, have suggested that the research aimed at recognition of the factors of immunological reactivity will involve difficulties, because a number of the data obtained seem to be valid only under the employed experimental conditions that are insufficient for any general conclusions.

In support of this statement it is possible to point to the differences found with the reactivity to two different antigens observed in experiments. While $B$ a $c$ o $n$ et al. (1986) observed that the general antibody response in chicks inoculated using SRBC or BA was invariably in favour of the former antigen, the results of our observations indicated repeatedly just the opposite.

Similar contradictions or differences were detected also for the genetic determination of responsiveness to different antigens. $\mathrm{U}$ b o s i et al. (1985b) observed, in their studies of the lines obtained with the use of divergent selection for the antibody response to SRBC, that it was possible to demonstrate better their differences under the conditions of primary than secondary responses; that the responsiveness in reciprocal hybrids was intermediary with respect to the parental forms, and without mutual differences; and that all these facts could be changed by administration of a different (larger) dose of SRBC. G y 1 e s et al. (1986) reported low estimates of the heritability of antibodies to SRBC ranging from 0.00 to 0.15 , the estimates from regression of progeny on sire being of zero value and those from regression of progeny on dam varying within the $0.10-0.13$ range. The opposite situation was observed in the reactivity to NDV (Newcastle disease virus), where the former values were higher varying between 0.00 and 0.30 and the latter were low ranging from 0.04 to 0.08 . 


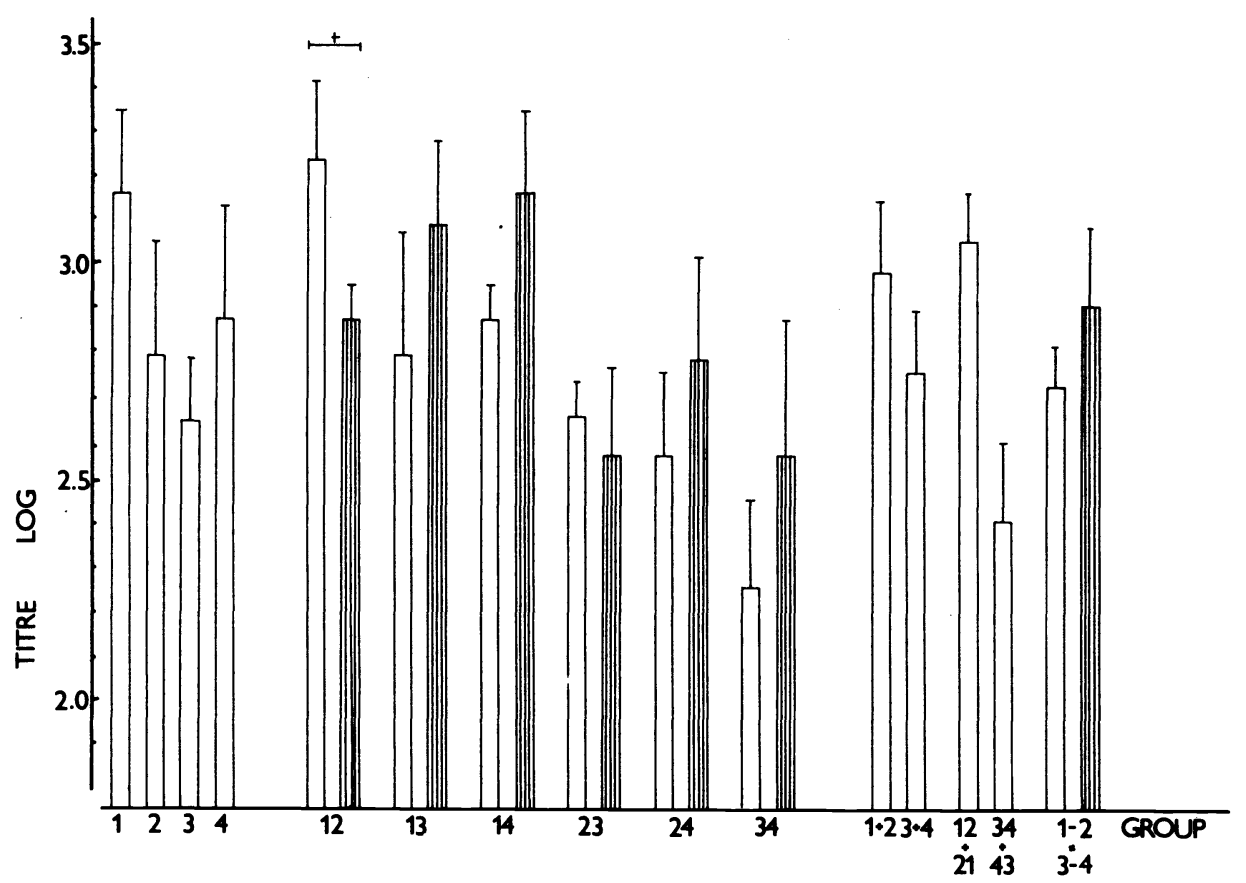

Fig. 2. Secondary antibody response to BA (mean, SEM). For details see comments to Fig. 1

In this particular case the authors considered existence of the maternal effect transmitted via the egg, which tended to reduce the genetic variance of the antibody titres to NDV.

The results reported in this paper were obtained from the experimental material coming from matings in which one hen from each of the four lines under study was inseminated using the sperm of one male of the given line. This arrangement of the experiment led to reduced variability, which could manifest itself in the significance of differences or, at least, in repetition of the tendencies that otherwise could be masked by the high variability of immunological reactions. The patrocliny observed in the crosses in antibody responses to either antigen, which, in all probability, may be explained on the basis of its determination by a sex-linked major gene (as suggested by $v$ a $n$ e $r \quad Z$ i j p and $N$ i e $u$ w l a $n d$ 1986), was one most striking result of observation in this study. Moreover, the differences found in the reactivity to BA and SRBC with the WL and RI hybrids may be also 


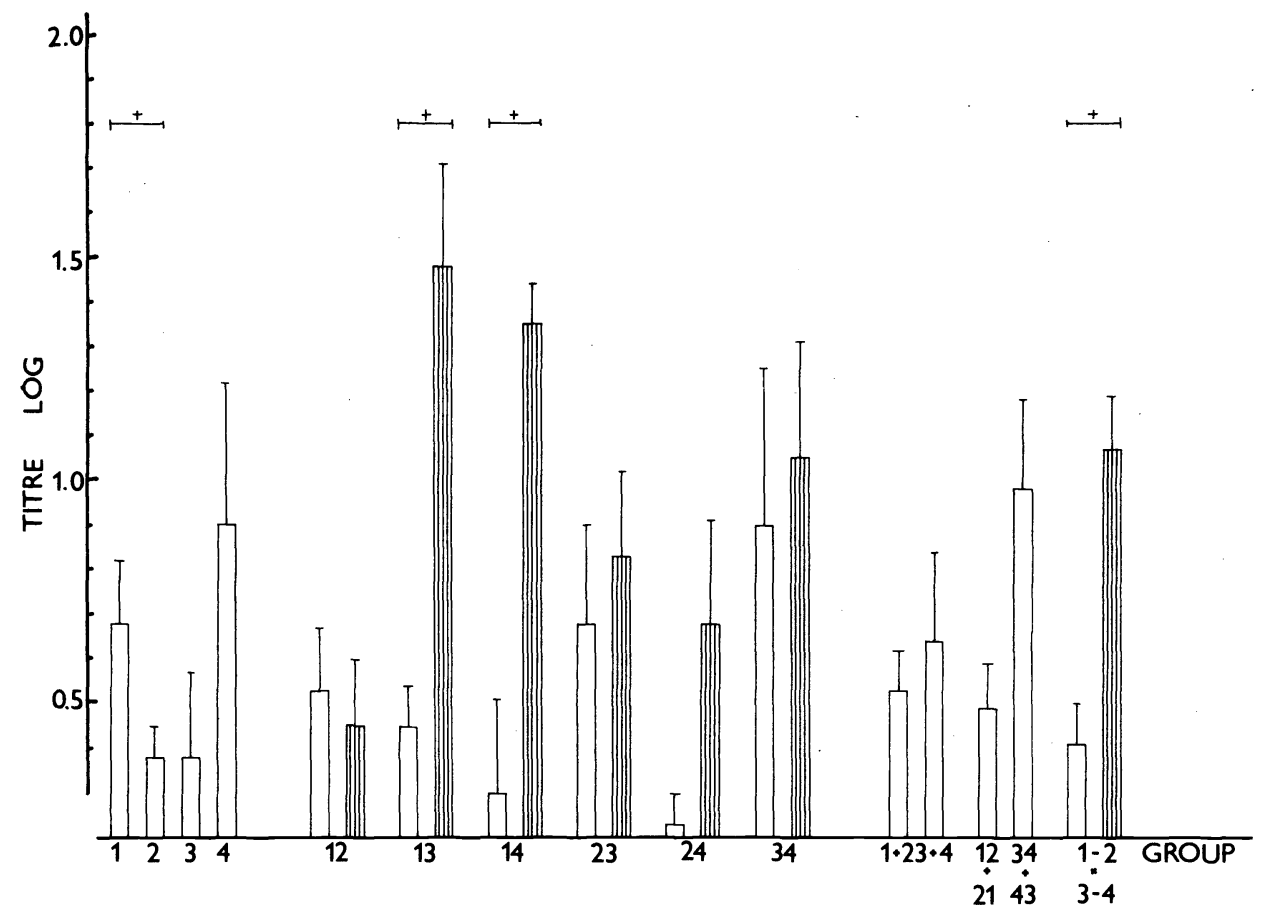

Fig. 3. Primary antibody response to SRBC (mean, SEM). For details see comments to Fig. 1 .

taken for important, in view of the well-known differences established in their viability under aggravated environmental conditions. No explanation is available in professional literature concerning our findings that the relations between the titres of antibodies to either antigen were also different with the breeds and crosses possessing different paternal forms. Both these achievements are intended to serve as a basis for further investigations in the genetic control of humoral immunological reactivity of domestic fowl and in the relation to the traits important in economic respects.

Genetické rozdíly v humorální imunitní reaktivitě u kura

U slepic čtyř komerčních linií plemen LB a RI (RIR, RIW) a dvanácti skupin jejich kříženců byla sledována tvorba aglutininů po jejich simultánní i.v. imunizaci ve věku 14 mĕsíců dvěma antigeny - Brucella abortus a ovčími erytrocyty, provedené dvakrát s odstupem 10 dnů, přičemž litr proti- 


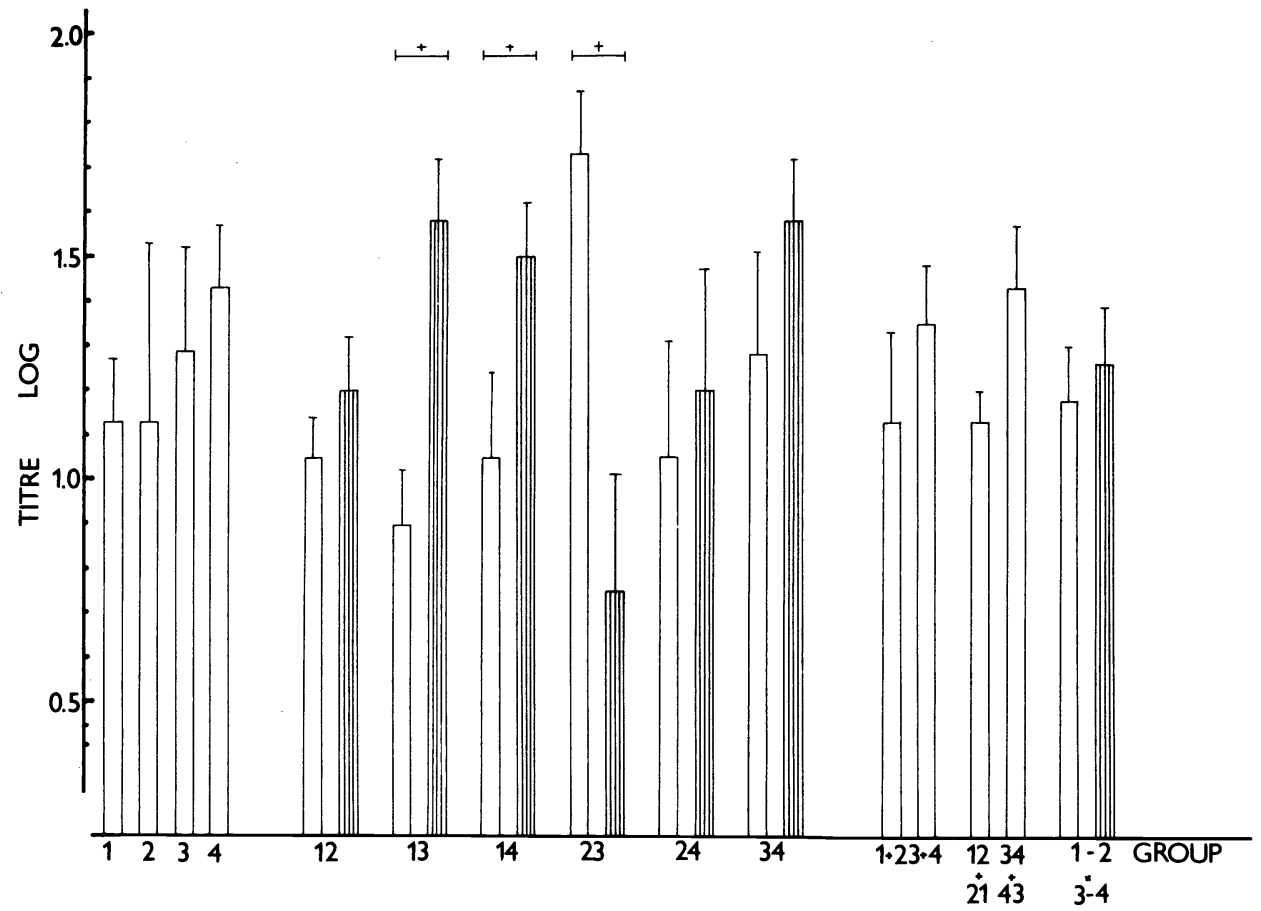

Fig. 4. Secondary antibody response to SRBC (mean, SEM). For details see comments to Fig. 1.

látek byl stanoven 10. a 15. den pokusu. Ve všech skupinách a $\mathrm{v}$ obou odpovědích byly titry protilátek proti prvnímu antigenu vyšší. Byly pozorovány rozdíly mezi liniemi $\mathrm{v}$ rámci plemen LB i RI, mezi plemeny LB a $R I$ - $v$ podobě vyšší reaktivity prvého plemene vůči B. abortus a naopak odpovídavosti nižší proti SRBC, a patroklinita u hybridů, $\mathrm{a}$ to $\mathrm{u}$ obou antigenů. Plemenná př́íslušnost $\mathrm{u}$ linií a otcovské linie u kř́ženců ovlivnily také vztahy mezi titry protilátek proti oběma antigenům.

Генетические различия в Гуморальной иммунитетной реактивности курицы

У күр четырех коммерческих линий пород WL и RI и двенадцати групп их гибридов исследовано образование агглютининов после их симультанной интравенозной иммунизации в возрасте 14 месяцев двумя антигенами - Brucella abortus и овчинными эритроцитами, проводившейся два раза С промежутками времени в 10 дней, при этом титр антител был определен на 10-ый день проведения опыта. Во всех 
Table 1

Relations between antibody responses $\left(r^{2} / F\right)$

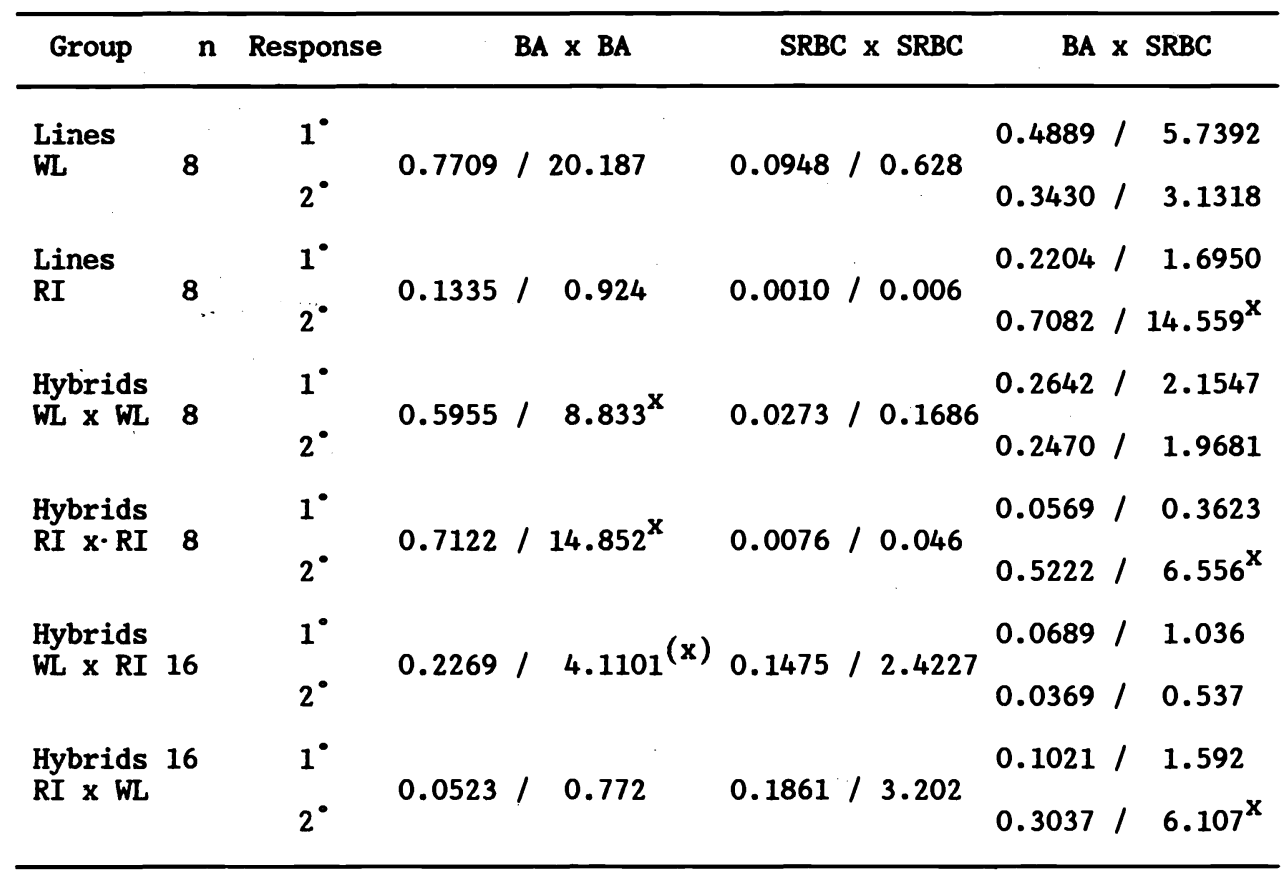

$\mathrm{x}$ - significant at $\mathrm{P}=0.05$

группах и обоих ответах титры антител по сравнению с первым антигеном находились на более высоком уровне. Установлены различия между линиями в рамках пород WL и RI, между породами WL и RI в виде более высокой реактивности первой породы $K$ B. abortus, и, наоборот, низшей отзывчижости к SRBC, и патроклинитет $Y$ гибридов, a именно $\mathrm{Y}$ обоих антигенов. Принадлежность к породе $y$ линий и отцовской линии Y Гибридов оказали воздействие на взаимоотношения титров антител к обоим антителам.

\section{References}

BACON, L.D. - FADLEY, A.M. - CRITTENDEN, L.B.: Absence of Influence on Immune Competence by the Sex-linked Gene (K) Determining Slow Feathering in White Leghorn Chickens. Avian Diseases, 30, 1986: $751-760$.

DUNNINGTON, E.A. - MARTIN, A. - BRILES, W.E. - SIEGEL, P.B.: Resistance to Marek $s$ Disease in Chickens Selected for High and Low Antibody Responses to Lower Case "s" Sheep Red Blood Cells. Arch. Geflügelk., 50, 1986: 94 - 96 . 
GYLES, N.R. - FALLAH-MOGHADDAM, H. - PATTERSON, L.T. - SKEELES, J.K. WHITTFILL, C.E. - JOHNSON, L.W.: Genetic Aspect of Antibody Responses in Chicken to Different Classes of Antigens ${ }^{1,2}$. Poult. Sci., 65, 1986: $223-232$.

HUTT, F.B.: The Utilization of Genetic Resistance to Disease in Domestic Animals. Proc. of XI. Int. Congress of Genetics, The Hague, 1963.

KLINGENSMITH, P.M. - DONAHOE, J.P. - STEPHENS, J.F.: The Effect of the Sex-linked Dwarfing Gene, dw, on the Immune Responses of Broiler Breeder Chickens ${ }^{1}$. Poult. Sci., 62, 1983: 733 - 740 .

NORDSKOG, A.W.: Selection for Immune Response as Related to the Major Histocompatibility Complex (MHC). Ann. Agric. Fenn., 23, 1984: 255 - 259.

PETROVSKÝ, E. - KALOVÁ, J. - BENDA, V.: Humoral Immune Response in Domestic Fowl of Different Genotypes. Proc. of $7^{\text {th }}$ Int. Symposium "Actual Problems of Avian Genetics", Smolenic, 1978b: 260 - 265.

PETROVSKÝ, E. - KALOVÁ, J. - BENDA, V.: Antibody Response in Domestic Fow1 as Affected by Different Immunization Methods. Acta Vet. Brno, 1987a, in press.

PLACHÝ, J. - BENDA, V.: Hlavni histokompatibilni komplex (B) kura domácího a jeho vztah $k$ některým nádorovým onemocněnim. Biol. 1isty, 48, 1983: $26-35$.

UBOSI, C.O. - GROSS, W.B. - SIEGEL, P.B.: Divergent Selection of Chickens for Antibody Production to Sheep Erythrocytes: Age Effect in Parental Lines and Their Crosses. Avian Diseases, 29, 1985a: 150 - 158.

UBOSI, C.0. - DUNNINGTON, E.A. - GROSS, W.B. - SIEGEL, P.B.: Divergent Selection od Chickens for Antibody Response to Sheep Erythrocytes: Kinetics of Primary and Secondary Immunizations. Avian Diseases, 29, 1985b: $347-355$.

Van der ZIJPP, A.J.: Breeding for Immune Responsiveness and Disease Resistance. W.P.S.A. Journal, 39, 1983: 118 - 131.

Van der ZIJPP, A.J. - NIEUWLAND, M.G.B.: Effects of Selection for Antibody Production on Immune Traits in the Chicken. Abstracts XX ${ }^{\text {th }}$ Int.

Conf. Anim. Blood Grps and Biochem. Polymorph., July 28 - August 1, 1986, Helsinki, p. 117.

Van der ZIJPP, A.J. - SCOTT, T.R. - GLICK, B.: The Effect of Different Routes of Antigen Administration on the Humoral Immune Response of the Chick. Poultry Sci., 65, 1986: 809 - 811.

tRequests for reprints should be addressed to Dr. Vladimir Benda CSc. 